\title{
Protipomenskost v Trubarjevem Katehizmu z dvejma izlagama iz leta 1575
}

\author{
IRENA OREL \\ Univerza v Ljubljani, Filozofska fakulteta, Aškerčeva 2, \\ SI-1000Ljubljana,irena.orel@ff.uni-lj.si
}

\begin{abstract}
V prispevku bo z različnih vidikov osvetljena sistemska in besedilna raba protipomenskosti v Trubarjevem najbolj polemičnem besedilu, Katehizmu z dvejma izlagama (1575), ki dvojnost razlage poudarja že v naslovu, versko nasprotnost pa izraža tudi v Pridigi od stare prave inu krive vere, ki bo natančneje razčlenjena.
\end{abstract}

The paper will illustrate the systematic and textual use of antonymy in Trubar's most polemical text, Catehismus s dveima islagama (Catechism with Two Interpretations) which emphasises the duality of interpretation in its very title, while the religious dichotomy is also expressed in the Pridiga od stare prave inu krive vere (Sermon on the Old, True Faith and the False Faith) which will be analysed in more detail.

Ključne besede: zgodovina slovenskega knjižnega jezika, 16. stoletje, Primož Trubar, zgodovinsko pomenoslovje, protipomenskost

Key words: the history of the Slovene standard language, $16^{\text {th }}$ century, Primož Trubar, historical semantics, antonymy

\section{Uvod: Protipomenskost v protestantskih nabožnih besedilih in pri Trubarju}

0.1 V verskih besedilih protestantskih avtorjev predstavlja medleksemsko razmerje protipomenskosti, ki se pojavlja v obliki antiteze kot ene od temeljnih retoričnih prvin antične in humanistične retorike, učinkovito sredstvo za izražanje utemeljevanja svojih in zavračanja nasprotnih trditev. V številnih izdajah katehetičnih in verskih besedil, razlagajočih osnovne nauke, člene evangeličanske vere prevladuje vloga prepričevanja in (proti)dokazovanja. 
Začetnika reformacije na Slovenskem Primoža Trubarja pa sta spodbudila k ostremu in učinkovitemu odgovoru in povzročila nastanek tega katekizma izida danes neohranjenega katoliškega Pache(r)neckerjevega katekizma iz 1. 1574 $\mathrm{v}$ slovenskem jeziku (Compendium catechismi catholici in Slavonica lingua per questiones in gratiam catholicae juventutis propositum), ${ }^{1} 1.1775$ pa prav tako v Gradcu izšla ostra jezuitska kritika, disputacija »zoper našo cerkev in vero«, o katerih piše Trubar na začetku nemškega predgovora. Trubarjev tokratni katekizem vsebuje slovenski nagovor, nemški in slovenski predgovor ter štiri vsebinske dele: katekizem s kratko württemberško razlago, pridigo od stare prave in krive vere, hišno tablo s koledarjem in registrom ter agendo. Naslov sam je dvoumna sintagma, ki bi jo lahko razumeli v luči dveh verskih opredelitev, o katerih govori ne le pridiga, predgovor, temveč je rdeča nit mnogih protestantskih nabožnih besedil v boju »za pravo staro vero«, ali pa se konkretno nanaša na razlagi dveh teologov, navedeni v nemškem naslovu: Katekizem z razlagama gospodov Brenza in M. E. Vischerja; prvo M. Glavan (1996: 12) poveže s katekizmom, drugo s pridigo, za katero meni, da je prerasla v »izrazito izviren opis«.

0.2 Vsa tedanja besedila naših protestantskih piscev so služila za zagovarjanje njihovih verskih nazorov, kar se odraža v izbiri slogovnih sredstev, v antitetični nasprotnosti in dopolnjevalni protislovnosti kot tudi $\mathrm{v}$ uporabi čustvenostno polarizirajoče (črno-bele, negativno, tudi slabšalno in pozitivno naravnane) besedne, slovnične in besedilne protipomenske dinamike in prepletanj, ki se v tem katekizmu izkazuje tudi v polemičnem tonu do katoliškega katekizma. Za ponazoritev je izbran večji del iz Trubarjevega krajšega slovenskega nagovora, v katerem so okrepljeni protipomenski pari in izrazi, ki potrjujejo pogostnost in raznovrstno prepletenost protipomenskih razmerij na različnih ravneh in se kot rdeča nit ponavljajo skozi katekizem, na kar bo pokazano v prispevku. Slogovna večplastnost in umetelna oblikovanost je izražena v primeri z metaforično rabo protipomenskih dvojic (ovčica - volk) in simboliki kaljenja vode ter nesmiselnosti argumentacije dejanja z zamenjavo položaja vršilcev dejanja (zgoraj - spodaj) ter $\mathrm{z}$ očitajočim vrednotenjem vere in dajanjem slabšalnih oz. ironičnih (junaki) poimenovanj s stališča nasprotnikov (zepelavci, kecarji 'krivoverci'), kar avtor spretno zavrne s pobudo za nesprejemanje trditve nasprotnikov (moramo /.../ preslišati) ter razveže z navajanjem pravih uničevalcev stare prave vere (ti naši zuperniki, papežniki, junaki) v vrinjenem protivnem stavku, ki ga uvaja veznik temuč ter sklepnim preobratom v nasprotno izraženo lastno stališče, ubesedeno z opredelitvijo vere in glagolskega dejanja (nova, kriva vera - stara, prava izveličanska vera; zamečujemo, doli taremo - vučimo, deržimo):

${ }^{1}$ V Gradcu pri tiskarju Bartschu je izšla prva slovenska katoliška knjiga Kratki katoliški katekizem za mladino cistercijana iz Vetrinjskega samostana Lenarta Pache(r)neckerja, ki je umrl 30. 9. 1580 kot opat v samostanu v Kostanjevici na Krki; zanj izvemo iz Trubarjevega Katekizma, a doslej ni bil odkrit noben izvod. 
Lubi kerfzheniki, Mi, kir bomo ty Lutherski ${ }^{2}$ inu te noue Vere imenouani, moramo, koker prauio od te ouzhice, kir ie ofdolai vpotoku pyla, ie timu volku, kir ie ofgorai pyl, Vodo skalila, tudi preslishati, de fmo Sepelauci, kezarij, nouo kriuo Vero fazhenemo, to Staro famezhuiemo inu doli taremo. /.../ Temuzh ty nashi Juperniki, ty Papefniki fo ty ifti Iunaki, kir fo Jtaro prauo Boshyo vero /.../ preobernili, preftauili, prozh vfeli inu perftauili, Boshy fapuuidi fubper. Obtu kupite fa male denarie lete Buquice, Zheftu preberite, Taku bote Jneshli, De mi Lutershki to Staro, prauo, Ifvelizhansko vero vuzhimo inu dershimo, Bug shnega Duhum bodi fnami Amen. Vash Truber. ${ }^{3}$

\section{Teoretične podstave protipomenskosti v jezikovnem sistemu, besedilu in kogniciji}

1.0 Nasprotje v širšem smislu je ena od osnovnih kategorij človeških spoznavnih procesov, ki jim ustrezajo temeljna urejevalna načela za različna področja mišljenja. Psiholingvistične raziskave potrjujejo, da razmerje nasprotja predstavlja eno od dveh načel besednih asociacij, ki je precej pogostejša od sopomenskega, in je del pojmovnih usmerjevalnih in urejevalnih shem (Patzke 2000, 11).

1.1 Protipomenskost kot kategorija v logiki, ki temelji na logičnem nasprotju med dvema resničnostma, se odraža $v$ mišljenju in $\mathrm{z}$ besedami, označujočimi nasprotja, kar je splošna težnja človeške vednosti (Filipec 1985: 129), je v jezikoslovju obravnavana glede na njeno sistemsko in besedilno vlogo; prva se izkazuje na besedni in slovnični ravni, druga vključuje diskurzivno in sobesedilno nasprotovalnost. V pomenoslovju je obravnavana kot eno izmed paradigmatičnih in medleksemskih pomenskih razmerij.

1.2.0 Kot retorično-stilistična prvina se izraža predvsem v obliki antiteze, ki je definirana v klasičnih retorikah pri Aristotelu, Demetriusu iz Faleruma, Ciceronu in Kvintilijanu (Krašovec 1984a: 1). E. R. Curtius podaja razlago antiteze: »zveza dveh stavčnih členov, ki vsebujejo miselno nasprotje«, Lausberg pa jo opredeljuje kot protistavljanje dveh nasprotnih stvari ${ }^{4}$ (Krašovec 1984a: 3,5 ). Formalno se uresničuje kot protipomenski dvočlenski/veččlenski niz oz. dvojna, trojna ... formula.

1.2.1 Antitetičnost $\mathrm{v}$ biblijskem besedilu nastopa kot posebna stilistična figura, poimenovana z izrazom merizmi, ki so značilni biblijski stilemi protistavljanja pojmovnega sveta in zajemajo celoto kot dopolnjevalno enovitost (v katekizmu npr. dobro - zlo, nebo - zemlja, nebo - pekel, bog - hudič, bog - ljudje, telo - duša, telo - kri), kjer dva skrajnostna pola, bipolarne entitete, s predznakom pozitivnosti in negativnosti sooblikujejo komplementarno podobo sveta, pri čemer ima lahko en pojem tudi več različnih nasprotij. Merizem je

\footnotetext{
${ }^{2}$ Okrepljeni tisk in podčrtavo (samo pri glagolskih protipomenskih izrazih) v vseh navedkih je uvedla avtorica prispevka zaradi lažje prepoznavnosti protipomenk.

${ }^{3}$ Pisava skupaj in narazen pri ločilih upošteva nedosledni zapis v izvirnem besedilu, tako tudi v drugih navedkih iz Trubarjevega izvirnega besedila.

${ }^{4} \mathrm{~V}$ izvirniku se glasi: »Antitheton is the contraposition of two opposing res«.
} 
biblična figura, ki izraža celoto $\mathrm{z}$ dvema skrajnima deloma $\mathrm{v}$ simboličnem pomenu (Krašovec 1977, 1984b, po Novak 2004: 206).

1.2.2 V stilistiki na sobesedilni protipomenskosti temelji še kontrast, oksimoron, evfemizem in ironija (Filipec 1985: 132).

1.3.1 Protestantska verska, predvsem katehetična, besedila ${ }^{5}$ imajo v boju za uveljavitev idejnih sprememb nasprotovalno vlogo (teza - antiteza), dokazovalno/prepričevalno vlogo (argument - protiargument), polemično vlogo (verski boj: za - proti). Menjavanje upovedovalne perspektive in navajanja sodb tako s stališča zagovornikov kot nasprotnikov sproži zamenljivost polarnih antonimnih parov: kar je pravo, staro, dobro za eno stran, je krivo, novo, slabo za drugo in obratno; pojavlja se npr. na ravni kvalitativnega presojanja temeljnega religioznega termina (vere) s polarizacijo evangeličanskega in katoliškega dojemanja njene pojmovne vsebine, ki jo izražajo predvsem s stališča izročila, pravilnosti, pripadnosti, resničnosti: luteranska vera je staralprava/božjal izveličanska/resnična, katoliška pa njeno nasprotje: nova/krivalfalš/hudičeva Izlodejevallažniva.

1.3.2 V pragmatiki se $\mathrm{v}$ modalnost kot način izražanja referenčno-predikacijske vsebine izjave pri nekaterih jezikoslovcih uvršča tudi negacija, ki je ne moremo opisati na strogo logičen pozitivno-negativni način (Verschueren 2000: 191). Na razlaganje vpliva sobesedilo: negacija zajema del ali celotno predikacijo.

1.3.3 V teoriji diskurza je $\mathrm{v}$ govornih dejanjih argumentacija »racionalna, jezikovna in družbena dejavnost, katere namen je narediti kakšno stališče za poslušalca bolj ali manj sprejemljivo oz. bolj ali manj nesprejemljivo« (I. Ž. Žagar po F. H. Eemeren, R. Grootendorst, v Verschueren 2000: 429).

1.3.4 U. Patzke (2007) od sistemske antonimije razlikuje besedilno antonimiteto, ki jo raziskuje s konceptualnega, distribucijskega in komunikacijskofunkcionalnega vidika; ugotavlja besedilne funkcije besedno motivirane antonimitete, vlogo asociacij, tipologijo skladenjskega sobesedila, zgradbo in pomen mikrokonteksta, paralelizme, dopustne zveze in tematiko makrokonteksta idr.

1.4 Klasifikacija besedne protipomenskosti upošteva tako logične kot jezikovne parametre. Različni avtorji določajo različne vrste protipomenskosti, npr.: - polarna (stopnjevalna, vektorska), komplementarna (Filipec 1985);

- kontradikcija, kontrast, konverzija (Patzke 2000);

- zamenjavna ali konverzivna, dopolnjevalna ali komplementarna, skrajnostna ali polarna (stopnjevalna; usmerjena ali vektorska) (Vidovič Muha 2000);

- kvalitativna, koordinacijska, komplementarna, vektorska, konverzivna (Šarić 2007). ${ }^{6}$

${ }^{5}$ Figuro nasprotja v Trubarjevih publicističnih besedilih je s stališča verskih pojmovnih sklopov in področij raziskal J. Toporišič (1995, 352-362).

${ }^{6}$ M. Humar (2007: 563-569) je predstavila delitve in opredelitve protipomenk s stališča splošnega izrazja pri različnih avtorjih (Apresjanu, Lyonsu, Novikovu, Mistríku, A. Vidovič Muhi, L. Šarić, M. Golden). 


\section{Protipomenskost pri Trubarju}

2.0 Protipomenskost, nanašajoča se predvsem na vero, nauke, božje službe, njene predstavnike in dejanja $\mathrm{v}$ povezavi $\mathrm{z}$ vero, ki se uresničuje na besedni, slovnični in besedilni ravni, bo z jezikovnega vidika razčlenjena in preverjena predvsem v osrednjem delu katekizma z naslovom »Ena pridna inu potrebna pridiga, vkateri se preproftu inu faftopnu vuzhi, koku ty mladi inu preprofti ludie, kir ne vmeio fami brati, oli te cele Biblie ne imaio, mogo is tiga Catehifma to Prauo Staro Ifuelizhansko Vero Spofnati, Jpryzhati inu fagouoriti, Inu to kriuo falsh Papeshko faurezhi.« (CDI 40).

Zadnji del naslova izpostavlja dva tipična protipomenska niza, v katerih je izraženo polemično bistvo pridige in celotne vsebinske zasnove, ki se z variacijami v besednih zvezah ponavlja na različnih mestih (v tem primeru sicer tročlenska zgradba razpade na dvočlensko z nesomernim protistavljanjem in manjkajočim členom na drugi strani: pravo - krivo, falš 'slabo, nepravo'; staro -; izveličansko - papeško). Nesorazmerje (3: 1) je razvidna tudi iz glagolskega protistavljanja z značilno pomensko izbiro glagolskih dejanj spoznavanja, dokazovanja, zagovarjanja ter zavračanja: spoznati, spričati inu zagovoriti-zavreči.

2.1.1 Na izrazni ravni običajno protipomenke nastopajo v parih oz. veččlenskih nizih, ki se med seboj besednovrstno ujemajo in dopolnjujejo: samostalniške, prevladujoče pridevniške, glagolske, prislovne, redkeje pa tudi predložne in členkovne priredno ali soredno povezane dvojice, trojice oz. nizi, ki so lahko besedilno povezani, so del istega stavčnega člena, tvorijo t. i. dvojne in večkratne formule, ali pa so razdruženi. Npr. v daljšem slovenskem predgovoru (CDI 12-19) Trubar napoveduje vsebino pridige in naniza značilne v besedilu se ponavljajoče pridevniške protipomenske dvojice (zlasti pogost je kvalitativni časovni (stari - novi) in komplementarni vrednotenjski (pravi - krivi) par, z vmesno slogovno učinkovito vpeljavo zamenjave protipomenskih členov (od noviga inu stariga češčena)), nanašajoče se na vero, krščevanje, čaščenje, na dodatno skrajnostno opredelitev kristjanov pa se navezujejo protipomenski pridevniki oz. samostalniki v ločnih prirednih samostalniških zvezah (bodi - bodi, oli), pa tudi v dostavčni stopnjevalni krajevni določitvi z dvodelnim veznikom nekar samuč - temuč tudi:

Sem tudi vletih Buquizah vti dolgi Pridigi, od fazhetka te Stare inu Noue, te praue in kriue Vere, od ftariga inu nouiga kerszhouana, Obhayla, od prauiga inu kriuiga, od nouiga inu Jtariga zhefzhena te Diuice Marye inu vfeh Suetnikou, Szhim inu koku more en vfaki kerfzhenik, bodi vuiffokim oli vniskim Jtanu, bodi ceffar oli paftyr, nekar famuzh vti Cerqui inu ob Prafniku, temuzh tudi na Rotaushi, doma na Puli, Bogu prou slushiti (CDI 17).

2.1.2 Protipomenskost se pogosto pojavlja tudi razdruženo v dvodelnih naštevalnih nizih z upoštevanjem ustreznega zaporedja členov v obeh nizih, ki ustvarjajo protipomenske dvojice, ali pa izražajo le neprimerljive pozitivne in negativne lastnostne oznake, kar v zgledu dopolnjujejo tudi priredno naštete glagolske sestavljenke s skupno podstavo (CDI 15-16, Predgovor): 
/B/odo tudi mogli inu veidili, to nasho prauo Jtaro vero, vfakimu Papeshnikouimu fuper gouorienu odgouoriti, Jagouoriti inu fprizhati de ta nih Vera, ie Noua, kriua, falsh, lashniua, hudizheua inu Malikouska, kir te ludi odpelaua inu fapelaua.

2.1.3 Protipomenke se pojavljajo tudi $v$ dveh stavčnih ali povednih enotah, ki je lahko še posebej polarizirana $\mathrm{z}$ uvedbo posamostaljene oblike glavnega števnika (eno) in drugostnega zaimka (drugo), npr.: »Tи епи ie zheftnu, prauu inu dobru. Tu drugu ie pag hudu, shpotliuu inu fafromouanu" (CDI 222), oboje avtor še nadalje pojasnjuje s ponovitvijo lastnostnih opredelitev pri pozitivni kvalifikaciji oz. z njihovo variacijo pri negativni: »Tu zheftnu, prauи inu dobru ie letu /... / Tu drugu pag kriuи inu hudizheuи ie letu /.../«. Pomensko zgornji primeri niso razvrščeni tako, da bi tvorili nasprotnopomenski niz, delno pa lahko prepoznamo nasprotne pare (častno - špotljivo, zasramovano; dobro - hudo (hudičevo), pravo - krivo pa se pojavi v pojasnilu).

\subsection{Vrste (med)leksemskih protipomenk}

2.2.0 Protipomenskost kot medleksemsko pomensko razmerje bomo ob različnih delitvah ${ }^{7}$ obravnavali v skladu s slovensko razvrstitvijo in razločili dopolnjevalne ali komplementarne, skrajnostne ali polarne, s podzvrstema stopnjevalnih in usmerjenih ali vektorskih, ter zamenjavne ali konverzivne protipomenke. ${ }^{8}$

2.2.1 Dopolnjevalni pari, ${ }^{9}$ tj. biblijska stilistična figura, imenovana merizem, glede na različne pomenske razsežnosti tvorijo ponavljajoči se stilem predstavljanja celote $\mathrm{z}$ dvema skrajnostma, ki se nanaša na splošna dejstva, stanja (npr. na vodi inu na suhim; te mertve obuditi /.../ te žive soditi (CDI 14, Predgovor) - v prvem členu sta v protipomenskem razmerju tudi glagolsko dejanje in desni delovalnik (mrtev 'brez življenja', obuditi 'dati življenje'); pri samostalniških živih dopolnjevalnih parih je poudarjena ali pojasnjena celota glede na posamezne člane, vlogo, spolsko različnost (npr. sin, šči; oča, mati; gospodar - gospodina, hlapčiči - deklice; hlapec, dekla). Dopolnjevalnost se pogosto pojavlja pri verskih pojmih, ki ubesedujejo idejne razlike med luteranskimi in katoliškimi verskimi nauki, členi (npr. lutrski - papeški/ papežovi; duša - telo: »ie meni dal to Dußho inu Tellu» (CDI 66), »na dushi

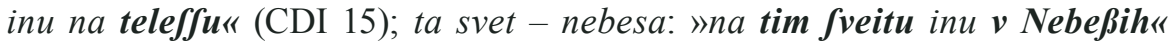
(CDI 34), nebesa - pekel; za ženina inu nevejsto; duhovski inu deželski; te telesne inu duhovske pomoči iskati; meso - duh: "(kir ne hodio) po tim

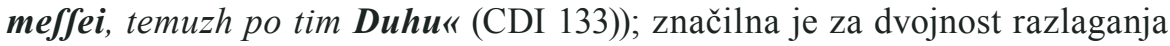

\footnotetext{
${ }^{7} \mathrm{O}$ tem prim. točko 1.4 .

${ }^{8}$ Tako je razvrstila protipomenskost A. Vidovič Muha (2000: 169-174, 2005: 215-220), ki je za izhodišče členitve upoštevala možnost njihovega vplivanja na delovalniške vloge znotraj stavčne povedi (2000: 169) ter kot prvo navedla zamenjavno skupino (2000: 170).

${ }^{9}$ A. Vidovič Muha omenja, da Hansen in Lyons ne obravnavajo dopolnjevalne protislovnosti pri antonimiji, temveč samostojno (2000: 169).
} 
vere, božjih služb in nastopa najpogosteje v lastnostnopridevniških določilih ob jedru (resnična - lažniva, prava - kriva (vera) idr.) ali z razlago ob izpostavljeni dvojnosti razumevanja verskega pojma, izraženi s števnikom dva: npr. ") le letema nerftarishema Bratama, fo fe te duei Veri, ta kriua inu ta prava fazhele« (CDI 50); dvojnost grehov se terminološko ubeseduje s sopomenskima izrazoma, ki sta v protislovju (naglavni-mali, mrtvaški odpustljivi): npr. »duy Grehi, Ty Naglauni oli mertuashki /.../ Ty mali pag inu odpuftliui Grehi» (CDI 130-131).

2.2.2 Skrajnostna (polarna) protipomenskost temelji na dveh nasprotnopomenskih skrajnostih, ki se ne dopolnjujeta; izražata lastnostno ali prostorskočasovno nasprotje..$^{10}$ Načeloma jih določa prisotnost vmesnega, tretjega člena kot srednje vrednosti med obema skrajnostma (Vidovič Muha 2000: 171-172). Kot podskupina skrajnostnih protipomenk se pojavlja stopnjevitnostna protipomenskost, kjer gre za hkratno in vzporedno leksikalno premikanje po skali ene in druge protipomenke proti srednji vrednosti (npr. vrel - vroc - topel (srednji) - hladen - mrzel - leden). Skrajnostne protipomenke so zelo pogoste: prevladujejo lastnostne pridevniške in prislovne dvočlenske protipomenke, ki prostorsko-časovno (po mejstih inu vaseh, čez te dežele inu mejsta, deželski inu mejstni (Bogovi); nuč inu/tar dan), kakovostno (vrstno, izvorno, objektivno in subjektivno vrednotenjsko, pripadnostno ipd.), opredeljujejo splošna dejstva: npr. lastnosti: bog oli bogat; bozi, bogati; mlad - star; nov - star; petler inu bogat); vrsto razlage: »zhaßi kratku, zhaßi dolgu iflagaio« (CDI, 12, Predgovor); »Ta Catehifem skratkimi inu dolgimi Islagami« (CDI, 16, Predgovor); položaj: nizkiga inu visokiga stanu, nizka - visoka gospoščina (CDI 318), »vfi Gofposzhini, mali inu veliki, duhouski inu deshelski (CDI 255) idr.

2.2.3.1 Usmerjene ali vektorske protipomenke izražajo različna nasprotnopomensko motivirana dejanja ali stanja, katerih uresničitev je (medsebojno) pogojena: v CDI se pojavljajo npr. v nekaterih sobesedilih v zvezah: doli sesti - vstati (»doli feifti inu spet od mife vftati« (CDI 126); na posodo jemati/dolge delati/biti dolžen - plačati/povrniti; dati - povrniti; biti dolžni - dati/plačati (npr. »na puffodo iemlo, dolge delaio inu ne mißlio oli ne hote Spet plazhati oli pouerniti« (CDI 129); »Ta Neuernik iemle na puffodo inu ne plazha, ampag ta prauizhen, ie miloftiu inu povrazhuie« (CDI 129)), nidati se/sovražiti - ljubiti: »e ne nidaio oli fovrashio, temuzh lubio« (CDI 307) - v tem primeru sopomenskemu prvemu členu dvojice ustreza en protipomenski izraz; vprašati odgovoriti - gre za tipični, ponavljajoči se in besedilno utemeljen usmerjenostni par: »vprashaiozh inu odgouorezh" (CDI 13, Predgovor), vprašane-odguvor; odpustiti - zadržati: »katerim vi te Grehe odpuftite, tim fo odpufzheni, Inu katerim vi fadershite, tim So fadershani« (31); prinesti - ponesti 'odnesti': »Mi

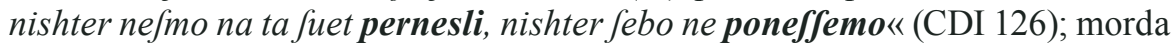
tudi vzeti - ohraniti (»ohrani, brani inu pobulsha« (CDI 126), prositi - dobiti (CDI 125), gori narejati - doli treti itd.

${ }^{10}$ Pri Šarićevi (2007) so obravnavani kot kvalitativni in koordinacijski antonimi. 
2.2.3.2 Poseben tip so besedotvorno (predponsko) različni primeri, ko je podstava enaka, protipomenska pa le predpona. Protipomenske usmerjene so nekatere glagolske sestavljenke s takimi predponskimi obrazili: za-: pre-, v-: iz-, pri-: od-itd.: zapovedati inu prepovedati: »kar Bug hozhe od nas imeiti oli nekar, fapouedanu oli prepouedanu « (CDI 15, Predgovor); fapouiduie inu prepouiduie (CDI 13, Predgovor); odpeljavati - zapeljavati: „od Buga, od nega beffede inu pokorszhine odpelaua inu fapelaua vta Pekal« (CDI 16) itd. Take dvojice pa pogojno tvorijo tudi netvorjenke s predponskimi obrazili, ki opomenjajo nasprotno dejanje ali usmerjenost proč od kod: reči - odreči, itioditi, gnati-od-/pregnati.

2.2.4 Zamenjavne ali konverzivne protipomenke so redke: povzročajo spremembo delovalniških vlog: uporaba enega ali drugega leksema iz protipomenskega para zahteva različna delovalniška mesta oz. različne delovalniške vloge (npr. dati - dobiti, dati - vzeti). ${ }^{11}$

2.2.5 Kvaziantonimija - sobesedilna protipomenskost se pojavlja $\mathrm{v}$ primerih, kjer nasprotja ne izražajo tipični nasprotni pari: npr. v naslednjem primeru sta protipol sovražnega pridevnika krotek in dobrotljiv: »Sludieua Cerkou ie Jourashna, nemyrna, Boshya pag ie krotka inu dobrutliua". (CDI 61); v svetem pismu - sam pri sebi, v lastni norski pameti; »de ie en Bog /.../ de Greshnike shtraifa - te dobre lubi« (CDI 43), kjer je nasprotje izraženo na ravni desnega delovalnika in dejanja: grešniki - dobri, štrajfati 'kaznovati' - ljubiti.

\subsection{Slovnične protipomenke}

\subsubsection{Besedotvorna protipomenskost}

2.3.1.1 Istokorenske protipomenke se razlikujejo po besedotvornih predponskih obrazilih, ki izražajo zanikanje ali odsotnost podstave (ne-, zuper-, anti- le v antikrist, antikrišst (Anticrishtu (CDI 122)), antikrištov, v nemškem posvetilu tudi psevdo- (das dise Socij Pseudochristi)). Tudi predponsko obrazilo presni bilo produktivno (pojavi se le v prezmeren).$^{12}$ Prevladujejo sestavljenke $\mathrm{z}$ zanikanjem lastnostnega pridevnika ali prislova, današnje predponsko obrazilo proti-, ki v starejših obdobjih večinoma izraža usmerjenost in ne opozicije, zamenjuje zuper $\mathrm{z}$ glasovno dvojnico zubper, ki pa se večinoma ne spaja z glagolsko podstavo, ampak tvori glagolske zveze s predložnosklonskim morfemom zuper, razen v zuperstati (zuperstati oli preoberniti) (CDI 107), v samostalniški tvorjenki zupergovorjene, pisani tudi narazen, zuper govorjene (»Odgovor, na nakateru tih Papeshnikou, vuzhenih inu preproftih fupergouoriene, fuper

${ }^{11}$ Zamenjavnost se pojavlja tudi pri stopnjevanju pridevnikov, a primerov zanje pri Trubarju nisem zasledila.

${ }^{12}$ Preverjeno je bilo v alfabetariju CDI kot internem slovarskem gradivu Inštituta za slovenski jezik. 
leta nash vuk od zheszhena tih Suetnikou« (CDI 210); »Papeshnikouimu fuper gouorienu odgouoriti« (CDI 18, Predgovor)), in v poimenovanju osebe (naši zuperniki (16 pojavitev v vsej knjigi)).

2.3.1.2 Zanikani lastnostni pridevniki (tudi v vlogi samostalnika) in prislovi tvorijo z nesestavljenimi večinoma dopolnjevalno dvojico: verni - neverni,

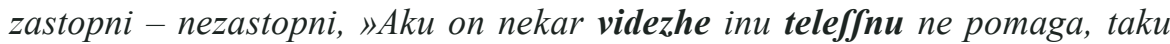
guishnu neuidezhe inu duhousku ohrani« (CDI 229) - v tem zgledu nastopata dva sopomenska para, ki sta v protipomenskem razmerju.

\subsubsection{Skladenjska protipomenskost}

2.3.2.0 Ker je skladenjska raba protipomenskosti kompleksno področje, ki zahteva samostojno raziskavo, naj na tem mestu opozorim samo na nekatera opažanja o skladenjskih posebnostih $\mathrm{v}$ tem besedilu oz. v starejših obdobjih.

2.3.2.1 V prirednih zvezah $\mathrm{z}$ vezalnim veznikom inu oz. redkeje $\mathrm{z}$ ločnim veznikom oli se pojavijo predvsem dopolnjevalne dvojice, ki nastopajo v različnih stavčnih vlogah, npr.: vernim inu nevernim, brati inu poslušati (oddajanje zvoka, sprejemanje zvoka); »kar fe nemu od eniga drugiga dobriga oli hudiga Jturi« (CDI 136) itd. Protipomenski prilastek lahko nastopa ob enakem (izpostavljenem) jedru: »fto ftaro kratko Islago. Inu potle feno obilno « (CDI 16, predgovor). Predložna zveza z zoper, ki je lahko postavljen za ali pred odnosnico, je del povedja: kot povedkovnik je zapostavljen in tedaj vezljiv z dajalnikom: nastopa $\mathrm{v}$ zvezah biti/stati komu zoper (npr. (je) božji zapuvidi/katekizmu/Bogu/naši visti/leteima dveima pridigama ... zuper/ zubper; »stoyte S. Duhu fuper « (CDI 52-53)); kot predložnomorfemski del desnega delovalnika nasprotuje desnemu delovalniku predvsem ob glagolih položaja, stanja, delovanja, bojevanja, govorjenja (npr. biti/stati/postaviti sel sturiti/dopernesti/dejati /grešiti zuper koga ali kaj; »ne dopufti nih vole /.../ Juper te Verne /.../ dopernefti« (CDI 122); bojevati se/vojskovati selpunt začeti zuper koga ali kaj; govoriti (npr. zuper greh govoriti, pridigal zuper tu rumane), kričati, pisati, pridig(ov)ati, reči, mrmrati, spričati, srditi se ... zuper koga ali kaj, z možno pretvorbo v samostalniško zvezo, izpeljano iz glagola (srd zuper nečistost); ali pa nasprotuje dejanju (npr. zuper reči oli spričati, stati zuper, biti zuper, zuper pridigovati). Predložna zveza s predlogom pres izraža odsotnost samostalniško izražene resničnosti (konkretne, abstraktne), s predlogom $z / s$ tvori protipomenski (zamenjavni) par ob različnih levih delovalnikih: npr. pres Ola, Crishme, pres Soly /.../ inu ftem olem fabelauaio, kerfzhuiemo (CDI 161-162). Dvodelne predložne zveze s skozi/iz česa v kaj izražajo prehajanje iz ene skrajnosti v drugo (iz slabega v dobro): »Oli on ie skufi to Iezho vto vezhno frayngo, skufi ta betesh inu shaloft vtu vezhnu fdrauie inu veßelie, skufi shpot inu Jafromouane, vto vezhno zhaft, Glorio inu v Maiefteto shal inu prishal.« (CDI 444). Posebne vrste je razvijajoča se skrajnostna protipomenskost ob istih nosilcih lastnosti, izražena skladenjskopomensko z glagolom storiti, ki z dejanjem izraža prehajanje lastnosti istih 
desnih delovalnikov v svoje nasprotje: Tu prizhouane tiga Gofpudi ie guishnu, Inu fturi te preprofte Modre (41). ${ }^{13}$

2.3.2.2 Medstavčna ali medpovedna protipomenskost se izraža s protipomenskimi stavčnimi členi ali/in z zanikanjem povedja ter s protivnimi prirednimi stavki: npr. »Inu ftem iftim, te Bolnike nekar de bi fdraui poftali, temuzh de leshei vmerio, masheio." (CDI 168), kjer ne gre za čisti opoziciji (postati bolan), ampak za sobesedilno izraženo posledično dopolnjevalno protipomenskost (živeti - lažje umreti), ki jo implicira glagol umreti. Desni delovalnik se ob glagolu spreminjanja sprevrže v svoje nasprotje: »De mi vtacih Boshyh slushbah, fmo tudi Nouino fazheli, premenili inu obernili na kriuino« (CDI 160). Vrednotenje poteka z ugotavljanjem pravilnosti trditve, dejanja ipd., pogosto je izraženo v ločni besedni zvezi s poudarjalno obliko nikalnice (nikar) in s povedkovnikom prav (ter tu ob glagolu ločevanja v predhodnem stavku: npr. »/D/e mogo v/sa Pifma, Pridige inu Nauuke, narafen lozhiti inu Jpofnati, kateri so prou oli nekar « (CDI 64). Prevladujejo protivni stavki s stilistično uporabljenim zanikanjem dejanja nasprotnikov ali somišljenikov v glavnem stavku, ki je razloženo trdilno $\mathrm{v}$ prirednem stavku, uvedenem $\mathrm{z}$ veznikom teтис̆, saтис́, ampag: npr. "Oli ta vegshi deil ludi, te praue Vere ne iszheio vtim S. Pifmu, temuzh per fui laftni norski pameti, oli per drugih ludeh, nih Starishih, inu per Jtarih Babah, Oli per nefaftopnih faryh inu Menihih « (CDI 43); »Mi vuzhimo ta praua dobra della, te praue Bogu dopadezhe slushbe, Ampag te Malikoushe, zlslaueiske(!) slushbe /... / famezhuiemo inu doli taremo etc. (CDI 323). Zanikanje je okrepljeno z nikalnimi zaimki, prislovi in členki, npr. »Guishnu drugdi nekar inu per nikomer, fe taku dobru nebeshku blagu ne naide, inu de ta zhlouik vtu vezhnu pogublene ne pryde, samuzh vtim S. Pifmu« (CDI 42). Dopolnjevalne protipomenke nastopajo pogosto tudi v stopnjevalnem priredju z dvodelnim veččlenskim veznikom nekar le saтис̌ - temuč tudi, ki lahko stopnjuje le en stavčni člen (npr. »de mi tako Iefufeuo Vezherio, nekar le famuzh nuznu temuzh tudi hvaleshnu vshiuamo« (CDI 441).

\section{Besedna in besedilna protipomenskost $\mathbf{v}$ Trubarjevi pridigi}

\subsection{Terminološka protipomenskost}

3.1.1 Besedila $z$ očitno pragmatično vlogo prepričevanja, še posebno polemičnega značaja, kjer je boj med različnimi podmenami, idejami, ideologijami, smermi, teoremi, teorijami ipd. prikazan v obliki teze in antiteze (pri Krelju v Otročji bibliji (1566) z naslovi opredeljene kot Thesis - Antithesis prave kristjanske in antikristjanske vere inu razločenje), s predstavitvijo obeh polov: pri Trubarju je izražena z nasprotnopomenskimi pridevniškimi izrazi, opredeljenimi glede na čas - prvotnost, vrednotenje oz. presojanje, izvornost, učinek:

${ }^{13}$ Oblikoslovno različno (tvorno - trpno) dejanje oz. stanje nekateri jezikoslovci uvrščajo med slovnično protipomenskost (inverzija povedka) (Martin 1976: 63). 
staralprava/božja/izveličanska/resnična - novalkrivalfalšlhudičevalzlodejeval lažniva vera, božje - malikovske službe. Opredelitev pomenskega polja vere (nauka, božjih služb) s prilastki v Pridigi od stare prave inu krive vere, ki se pojavlja okoli 100-krat, je prikazana tudi v naslednji preglednici s protipomenskimi pridevniškimi izrazi, opredeljenimi glede na:

- čas oz. prvotnost

stara : nova

- vrednotenje oz. presojanje

prava, resnična

kriva/falš, lažniva

- izvor

božja

- učinek, posledičnost

izveličanska

hudičeva/zludjeva

- način, sredstvo izražanja

- povezanost, vrstnost

ta luterska

škodliva

malikov(al)ska

- trajanje

- pripadnost

naša

papeška, ta papežova

stonovita, trdna

nih

Najpogosteje se kot levo prilastkovno določilo (ob veri) pojavlja vrednotenjski pridevnik prava, nato prava stara oz. stara prava ter svojilni zaimek naša $\mathrm{s}$ kombinacijami. Starost je v besedilu opredeljena za neustrezen argument: »/D/e fa volo te Starofti neifo fatu ve Vere prou inu od Buga poftaulene /.../ Sakai, te kriue Vere inu falsh slushbe Boshye, fo tudi Jtare, Od Sludia Vnebeßih inu od Adama Vparadishu fe fazhele.« (CDI 49).

Poleg metaforičnosti in ekspresivnosti izražanja tudi na protipomenski ravni je nasprotno pojmovanje starosti in pravilnosti vere: novo je nepravo, staro je pravo: zato nadnaslovi v besedilu katekizma: stara prava vera, stara prava molitov, prave službe božje, stara prava maša; te nerpridniše inu potrebniše artikule inu štuke te naše stare prave kerščanske vere. V pridigi se pridevnika stara in nova lahko nanašata na obe veri, vendar se uresničujeta pomensko različno: luterancem pomeni stara 'izvorna, prvotna', katolikom 'ustaljena, nespremenjena glede na sedanje stanje', nova pa obema 'spremenjena', le s to razliko da prvi pojmujejo spremembo glede na izhodiščno (preteklo) stanje, drugi glede na (sedanje) stanje, gre torej za različno časovno opredelitev starosti in novosti.

3.1.2 Samostalniki, ki poimenujejo pripadnike obeh ver, so povezani z njihovimi začetniki, voditelji oz. zagovorniki: za svoje somišljenike je uporabljeno posamostaljeno vrstnopridevniško poimenovanje (lutrski), tudi s poudarjeno vključevalno osebnozaimensko opredelitvijo $(\mathrm{mi})$, za nasprotnike pa je poleg variantnega splošnega izraza, izsamostalniške izpeljanke z obrazilom -nik (papežniki) v rabi izjemoma (enkrat) tudi svojilnozaimenska oblika na -ov (papežovi: »Tih Luterskih oli Papeshouih« (CDI 17)) ter zelo pogosto izraz zuperniki 'nasprotniki' (okrog 10-krat), ki poudarja polemično naravnanost in nasprotovalni odnos do verskih nasprotnikov, ki se negativno stopnjuje $\mathrm{v}$ skrajno poimenovanje sovražniki s konotacijo na verski boj. Izrazi špotljivci, kecarji, zapeljavci slabšalno označujejo posamezne lastnosti nasprotnikov: njihov zaničevalen odnos, krivoverstvo, zavajajoč način pridobivanja vernikov na svojo stran. Lahko so pospremljeni še z dodatnimi določili (nesramni, lažnivi, nezastopni papežniki; naši inu te božje besede sovražniki, naši inu božji 
zuperniki; ti naši preprosti inu vučeni zuperniki; božji, vseh svetnikou inu božji službi sovražniki, špotlivci itd.).

- verniki ti/mi luterski (luterški): papežniki (papežovi), zuperniki sovražniki, špotlivci

kecarji, zepelavci

3.1.3 Raba prislovov se ujema s pridevniki: novo v veri je poimenovano kot »kriuu, falsh, Sludieuu inu lashniuu, praui ta Jtari Vuzhenik Tertulianus« (CDI 48). Namesto pravi je včasih naveden tudi povedkovnik »prou«.

3.1.4 Glagoli se ujemajo z ostalimi poimenovanji: izražajo nasprotje: biti zuper (kateri so leti naši veri zuper), deržati za (zludjeve vere), deržati, gori staviti (krivo novo vero), imeti, izkazati, iztolmačiti, postaviti, rezodeti, terditi, vučiti, spoznati, spričati, zagovoriti, zapovedati (vero), odgovoriti tem zupernikom; doli treti, zametovati, zatreti, zavreči (staro vero); začenati, pridigati (novo vero), zašpotovati (svetnike); kričati, lagati, vpiti, pisati, veleti, čez nas (papežniki); izpačiti, premeniti, zatreti (službe božje) itd.

\subsection{Večvrstna protipomenskost}

3.2.1 Razvrednotenje nasprotnih stališč in izpostavljanje lastnih, negacija in afirmacija se jezikovno ubeseduje z nasprotnopomenskimi pari, z navajanjem pozitivnih in negativnih lastnosti, dejanj, postavk, z navajanjem sodb nasprotnikov in protiargumentiranja ipd. $\mathrm{v}$ prepletu skladenjske in leksikalne protipomenskosti. Trubar je pogosto vpletal v besedilo verske opredelitve s stališča svojih nasprotnikov, npr. v treh knjigah je razlagal "prauo ftaro Vero, katero mi, kir bomo od tih nefaftopnih, te Luterske noue kriue Vere imenouani, dershimo« (45). Na drugih mestih se belo-črna izbira lastnostnih potez povezuje z ujemajočo se izbiro dejanj oz. stanj. Dodatna metaforična motivacija iz sv. pisma za dejansko nesprejemljivo stanje, ki jo Trubar razveže, se nanaša na uboge, v božjih rečeh slepe, od svoje pameti in starejših zapeljane ljudi, ki: »hprauimu ftudenzu, kir bi nih sheio mogli vgafiti Ioh.4.7.efa.55, tu ie, Boshyo miloft dosezhi /... ne gredo, temuzh htim kalnim mlakom « (43-44), "ga ne pelaio po praui Cefti vnebeffa, temuzh po tih Neraunih kriuih ftefah vta pekal« (44). Nasprotni pojmovni pari so v besedilu navedeni ločeno in skladenjsko zanikani, tj. podani kot negativen zgled za neumestnost dejanja: vloga svetega pisma je kazanje prave ceste $\mathrm{v}$ nebesa in učenje, da ne pridemo $\mathrm{v}$ pekel (CDI 42): z vrednoto kot je »resnični nauk od te vere«, $\mathrm{z}$ iskanjem »prave ceste $\mathrm{v}$ nebesa« »dobimo ta vezhni leben«, »de ne prydemo vta Pekal, vta vezhni plazh, Iok, inu shkripane tih fob«, »vtu vezhnu pogublene« (CDI 42). Samostalniška nasprotja so omiljena s stavčno negacijo (zanikanim glagolom), ki poudarja neuresničitev dejanja. Kontrastiranje kot negativen zgled prepričuje o doseganju pozitivnega pola.

3.2.2 Trubar kot spreten ubesedovalec svojih prepričanj učinkuje večsmerno na zavest bralcev in jih utirja $\mathrm{v}$ svoje miselne okvire: tako z večstransko anti- 
tetičnostjo, prepričevanjem o nepravilnosti mnenja o sebi z nagovorom »ljubim Slovencem«, ponavljanji enakih bipolarnih, predvsem vrednotenjskih, določil ob predstavnikih vere in za vero samo ter za neustrezno vrednotenje načina razlaganja (pravi - krivi učeniki, prava - kriva vera, prave - malikovske božje službe; pravo - krivo, falš 'napačno'), stavčni protivnosti (z vezikom temuč, pag), izbiri glagolskih dejanj, s poudarkom na stavčni negaciji glagola zanikovanja, nanašajočega se na »ljubo« starost (zavreči), in zasmehovanja ( iz starih pravih »učenikov«) razločevanju med pravim in krivim (prave ločimo od krivih ...), pojasnjevanju dvojnosti »starejših« in »učenikov« (mi imamo duje stariše inu učenike) in delitvi na prave in krive, ki nasprotujejo (so zoper) svetemu pismu, evangeliju in katekizmu in nepravilno ter napačno razlagajo (izlegajo) sveto pismo, kar podkrepi s paralelizmom členov na različnih ravneh:

Vi tudi lubi Sloueni, ne imate nas fa take ludi dershati, de bi mi hoteli to lubo Staroft faurezhi, is tih Starih prauih Vuzhenikou shpot delati, tiga Bug ne dai, Temuzh mi lozhimo te praue Vuzhenike od tih kriuih, glih koker to prauo Vero, inu te praue Boshye slushbe od tih Malikouskih, fakai mi imamo duie Starifhe inu Vuzhenike, te praue Vere inu te kriue. Ty nashi praui Vuzheniki inu Starishi so ty S. Ozhaki, Preroki inu Iogri, Ty kriui pag Ło vfi ty, kir Lo S. Pifmu, timu S. Euangeliu inu Catehifmu fuper, kir kriuu oli falsh tu S. Pifmu iflegaio /.... (CDI 56).

\section{Sklep}

Premišljena in kompleksna izbira retoričnih sredstev (proti)argumentacije in slogovnih sredstev antitetičnosti, s katerimi Trubar ubeseduje nasprotna stališča in verska prepričanja, razpetost med dobrim in zlim, ločevanje med pravim in nepravim, pozitivno-negativno utemeljevanje pojmovanja vere, človekovega bivanja, delovanja, življenja, njegovih lastnosti in s katerimi zarisuje dvojno, zrcalno nasprotno in dopolnjevalno sliko sveta, razkriva učinkovitega retorika, prefinjenega stilista, ognjevitega zagovornika in bojevitega nasprotnika, ki je s pisano besedo in »z ostro peruto « zagovarjal svoja reformacijska stališča in prepričeval svoje bralce z močjo slovenske besede, ki se je razplamtela v vsej svoji udarni polnosti.

\section{VIRI IN LITERATURA}

Primož TRUBAR, (1575) 1996: Catehismus sdveima islagama. Ena pridiga od starofti te praue inu kriue Vere ... vkupe sbrana ... skufi Primosha Truberia. Faksimile. Ljubljana: DZS.

- -, (1575) 2003: Catechismus zdveima izlagama. Zbrana dela Primoža Trubarja II. Ur. Fanika Krajnc Vrečko. Ljubljana: Rokus. 37-410.

Zbrana dela Primoža Trubarja I-IV, 2007. CD. Ljubljana: Založba Nova revija. 
Jožica NARAT (s sodelovanjem M. Merše in F. Novaka), 1997: Alfabetarij Trubarjevega Catehismusa sdveima islagama iz leta 1575. Sekcija za zgodovino slovenskega jezika Inštituta za slovenski jezik Frana Ramovša ZRC SAZU (interna publikacija).

Mihael GLAVAN, 1996: Trubarjev Katehismus z dvejma izlagama. Priloga h Catehismus s dveima islagama: ena pridiga od starosti te praue inu kriue vere ... vkupe sbrana ... skusi Primosha Truberia. Ljubljana: DZS.1-21.

Marjeta HUMAR, 2007: Protipomenskost v sodobnih slovenskih terminoloških slovarjih. Orel, Irena (ur.): Razvoj slovenskega strokovnega jezika. Obdobja 24, Metode in zvrsti. Ljubljana: Filozofska fakulteta, Oddelek za slovenistiko, Center za slovenščino kot drugi/tuji jezik. 561-582.

Jože KRAŠOVEC, 1984: Antithetic structure in biblical Hebrew poetry. Leiden: E. J. Brill. Supplements to Vetus testamentum, 35.

Robert MARTIN, 1976: Inférence, antonymie et paraphrase. Strasbourg: Librairie C. Klincksieck.

France NOVAK, 1998: Besedje Trubarjevega dela Catehismus z dveima izlagama iz 1. 1575. Vatroslav Oblak, Obdobja 17. Ljubljana: Filozofska fakulteta, Oddelek za slovenistiko, Center za slovenščino kot drugi/tuji jezik. 233-249.

Vatroslav OBLAK, 1891: Doneski k historični slovenski dialektologiji II. LMS za leto 1891.

Dodatek. Trubarjev katekizem z dvema izlagama od 1. 1575. Ljubljana. 135-153.

Una PATZKE, 2000: Antonymische Relationen und Text. München: Verlag Otto Sagner.

Ljiljana ŠARIĆ, 2007: Antonimija u hrvatskome jeziku. Semantički, tvorbeni i sintaktički opis. Zagreb: Hrvatska sveučilišna naklada.

Jože TOPORIŠIČ, 1995: Die Figur des Gegensatzes in Trubers publizistischen Texten. Kluge, Rolf-Dieter (ur.): Ein Leben zwischen Laibach und Tübingen: Primus Truber und seine Zeit. Intentionen, Verlauf und Folgen der Reformation in Württemberg und Innerösterreich. München: O. Sagner. 352-362.

Jef VERSCHUEREN, 2000: Razumeti pragmatiko. Ljubljana: Založba *cf.

Federico VICARIO, 2003: Note sull'ordine degli elementi in di verbi antonimi. Linguistica XLIII. Ljubljana. 3-12.

Ada VIDOVIČ MUHA, 2000: Slovensko leksikalno pomenoslovje - govorica slovarja. Ljubljana: Znanstveni inštitut Filozofske fakultete. 169-174.

- -, 2005: Medleksemski pomenski razmerji - sopomenskost in protipomenskost. Jesenšek, Marko (ur.): Knjižno in narečno besedoslovje slovenskega jezika. Maribor: Slavistično društvo (Zora 32). 206-220. 


\section{SUMMARY}

In Trubar's Katekizem z dvejma izlagama (Catechism with Two Interpretations), written as a response to the publication of a Catholic catechism, the polemical tone and the defence of religious views that are characteristic of Slovene Protestant writings in general are highly polarised. This is reflected in the rhetorical/stylistic choice of lexico-syntactical antonymous dynamics with prevailing antonymous pairs in the role of antithetical contrast and complementary contradiction which corresponds to the pragmatic principles of argument and counter-argument. The positive or negative evaluation of socially, religiously and temperamentally defined groups of people and their moral and spiritual qualities - is typified by antithesis as the basic stylistic element of rhetorical prose (the contrasting conception of faith of Lutherans and Papists, who are called disagreeable, abominable, inimical) or by merism, a characteristic stylistic element of the Bible, which juxtaposes the conceptual world and comprehends it in its complementary uniformity (good-evil, heaven-earth, heavenhell, God-Devil, God-Man, body-soul, flesh-blood). At the lexical level, antonymy is most commonly expressed phrasally with a double formula or in an enumerative series by means of various grammatical devices: in conjunctive or disjunctive coordination (with the conjunctions inu, oli, bodi ... bodi) and in juxtaposition with radically different antonyms (father-mother, master-mistress, servant-maidservant, low-high, poor-rich, clerical-provincial, hate-love, true-false); morphologically with negational or antonymous prefixes (ø-/ne- (verni-neverni-believers-nonbelievers), zuper-, anti- (antikrista - Antichrist), za- / pre- (zapovedati, prepovedati - order, prohibit)); in verb phrases with the prepositional morphemes zoper, čez (biti / stati / reči / govoriti zuper koga ali kaj - to be, stand, speak against someone or something, vpiti / kričati / lagati čez / zuper koga - to shout, clamour, lie against someone). At the syntactical level it is verbalised clausally in prepositional phrases with the preposition prez, with negative particles and pronouns, with adverbs, and interclausally with adversative and intensifying coordinating conjunctions (temuč, ampak; nekar (le) samuč - temuč tudi). It frequently appears as a combination of multiple and manifold antonymous pairs or series. With regard to the verbalising perspective and the citing of arguments and counter-arguments from the point of view of advocates and opponents, there is an interchangeability of polar antonym pairs (the two series old / true / divine / veritable-new / false / diabolical / mendacious faith can apply both to Lutherans and to Catholics). 